\title{
Water table fluctuation in well/tube wells of Gir Somnath district of Gujarat
}

J.V. POLARA AND R.B. CHAUHAN

Received : 21.12.2015; Accepted : 30.05.2016

\section{MEMBERS OF RESEARCH FORUM:}

Corresponding author : J.V. POLARA, Department of Agricultural Chemistry and Soil Science, Junagadh Agricultural University, JUNAGADH (GUJARAT) INDIA

Email: jvpolara@jau.in

Co-authors :

R.B. CHAUHAN, Department of Agricultural Chemistry and Soil Science, Junagadh Agricultural University, JUNAGADH (GUJARAT) INDIA

Email: chauhanravi3612@gmail.com

\section{Summary}

In order to study, the fluctuation of well/tube well water table, 30 sites each from 6 talukas of Gir Somnath district from where water table depths were measured before and after monsoon. In all, 152 wells and 28 tube wells water table levels were studied in May, 2014 and again after $6^{\text {th }}$ month in November, 2014. The water table before monsoon (May, 2014) in wells and tube wells ranged from 4.58 to 42.81 and 15.29 to 122.32 with mean value of 17.21 and $59.96 \mathrm{~m}$, respectively. Surprisingly, water of some of the wells of all the talukas and tube well of Talala taluka rises gradually and were flowing freely on soil surface during the monsoon. At the end of the monsoon (November, 2014), the overall water table of Gir Somnath district in well ranged from 1.52 to 24.46 and in tube well from 3.05 to $76.45 \mathrm{~m}$ with mean value of 8.01 and $16.71 \mathrm{~m}$, respectively. The minimum fluctuation of water table $(8.46 \mathrm{~m})$ in well was observed in Kodinar taluka, whereas in tube well it was in Sutrapada $(38.48 \mathrm{~m})$ taluka. The maximum fluctuation of water table in well was observed in Una $(9.85 \mathrm{~m})$ taluka and in tube well in Gir Gadhada (61.16 m) taluka.

Key words : Water table fluctuation, Well/tube well

How to cite this article : Polara, J.V. and Chauhan, R.B. (2016).Water table fluctuation in well/tube wells of Gir Somnath district of Gujarat. Asian J. Soil Sci., 11 (1) : 243-245 : DOI : 10.15740/HAS/ AJSS/11.1/243-245. 